\title{
POLA FLUKTUASI POPULASI BAKTERI DI PERAIRAN PANTAI DAN TELUK PADA SENTRA BUDIDAYA IKAN LAUT DI BALI UTARA
}

\author{
Ketut Mahardika\#, Indah Mastuti, Reagan Septory, Des Roza, Zafran, dan Afifah Nasukha \\ Balai Besar Riset Budidaya Laut dan Penyuluhan Perikanan \\ Jalan Br. Gondol, Kec. Gerokgak Kab. Buleleng, Po. Box 140, Singaraja, Bali 81101
}

(Naskah diterima: 8 Juni 2020; Revisi final: 6 April 2021; Disetujui publikasi: 6 April 2021)

\begin{abstract}
ABSTRAK
Bakteri merupakan mikroorganisme yang secara alami berada dalam ekosistem perairan laut dan beberapa spesiesnya bersifat patogen. Penelitian ini bertujuan untuk menentukan pola fluktuasi populasi bakteri secara umum dan Vibrio spp. secara khusus di perairan pantai dan teluk sebagai dampak dari aktivitas baik panti pembenihan, tambak udang, maupun karamba jaring apung (KJA) di pesisir Bali Utara. Sampel air diperoleh dari tiga lokasi sentra budidaya laut dan satu lokasi ekowisata yang berada di Kecamatan Gerokgak Kabupaten Buleleng. Sampel air diambil dari tiga titik sampling di perairan dengan jarak 50 m, 100 m, dan 300 m dari garis pantai di Desa Gerokgak dan Desa Penyabangan. Sampling air dilakukan pada tiga titik sampling di sekitar KJA di Teluk Kaping, Desa Sumberkima, dan satu titik sampling di perairan dengan jarak $100 \mathrm{~m}$ dari garis pantai di Desa Pemuteran. Sampling air dilakukan sekali dalam sebulan dari bulan Februari hingga November 2018. Hasil penelitian menunjukkan bahwa total bakteri dan Vibrio spp. di empat lokasi perairan di Kecamatan Gerokgak, Bali menunjukkan populasi tinggi pada bulan Maret hingga Mei dan menurun pada bulan berikutnya. Dan meningkat kembali pada bulan Oktober hingga November. Total bakteri dan Vibrio spp. tertinggi terjadi di perairan pantai Desa Gerokgak hingga 9.067 $\pm 7.481 \mathrm{CFU} / \mathrm{mL}$ dan $1.147 \pm 689 \mathrm{CFU} / \mathrm{mL}$ dibandingkan dengan dua lokasi sentra budidaya lainnya (Desa Penyabangan dan Teluk Kaping). Total bakteri dan Vibrio spp. teramati pula di perairan Desa Pemuteran hingga $500 \pm 52$ $\mathrm{CFU} / \mathrm{mL}$ dan $65 \pm 7 \mathrm{CFU} / \mathrm{mL}$ yang kemungkinan merupakan dampak dari aktivitas budidaya ikan. Pola fluktuasi populasi bakteri di perairan pantai Kecamatan Gerokgak, Bali dipengaruhi oleh musim dan kegiatan budidaya perikanan. Tingginya populasi bakteri Vibrio spp. pada perairan pantai dapat memengaruhi kesehatan ikan budidaya.
\end{abstract}

KATA KUNCl: perairan pantai; total bakteri; Vibrio spp.

ABSTRACT: Fluctuation patterns of bacterial populations in coastal areas of a clustered marine fish farming of North Bali. By: Ketut Mahardika, Indah Mastuti, Reagan Septory, Des Roza, Zafran, and Afifah Nasukha

Bacteria are a group of microorganisms naturally present in aquatic ecosystems. Some of the bacteria are pathogenic
to other organisms and cause severe diseases. This study aimed to determine the fluctuation patterns of bacterial
populations, with specific interest to Vibrio spp. in coastal and bay areas of North Bali which constantly receive
effluents from nearby mariculture activities. Water samples were collected from three locations in a clustered marine
fish farming area and one location in an ecotourism area as a control. Water samples were taken from three sampling
points in the coastal area of Gerokgak and Penyabangan villages at a distance of $50 \mathrm{~m}$, $100 \mathrm{~m}$, and $300 \mathrm{~m}$ from the
coastline. Water samples were also collected at three sampling points around floating net cages (KJA) in Kaping Bay,
Sumberkima Village, and one sampling point in Pemuteran Village located $100 \mathrm{~m}$ from the coastline. Water sampling
was carried out each month from February to November 2018 . Results of the study showed that total bacteria and
Vibrio spp. were notably higher between March-M ay and October-November. The total bacteria and vibrio reached the
peak number at $9,067 \pm 7,481 \mathrm{CFU} / \mathrm{mL}$ and $1,147 \pm 68 \mathrm{CFU} / \mathrm{mL}$, respectively, which occurred in the coastal

\# Korespondensi: Balai Besar Riset Budidaya Laut dan

Penyuluhan Perikanan

Jalan Br. Gondol, Kec. Gerokgak Kab. Buleleng, Po. Box 140,

Singaraja, Bali 81101 , Indonesia

Tel. + 6236292278

E-mail: kmahardika@yahoo.com 
waters of Gerokgak Village. The total bacteria and Vibrio spp. of up to $500 \pm 52 \mathrm{CFU} / \mathrm{mL}$ and $65 \pm 7 \mathrm{CFU} / \mathrm{mL}$, respectively, were also observed in the waters of Pemuteran Village which are likely to be the effects of aquaculture activities in these of three locations. This study concludes that the fluctuation pattern of bacterial population in the coastal waters of Gerokgak District, Bali is primarily influenced by the season and activities of the fish farming. The high population of Vibrio spp. in the coastal waters could lead to a fish disease oubreak related to the pathogenic bacterium.

\section{KEYWORDS: coastal waters; total bacteria; Vibrio spp.}

\section{PENDAHULUAN}

Perikanan budidaya laut mengalami perkembangan pesat di Asia Tenggara, termasuk Indonesia. Negara Indonesia telah berhasil mengembangkan perikanan laut berbasis pembenihan ikan bandeng, Chanos chanos dan ikan kerapu, Epinephelus spp. Daerah pembenihan ikan bandeng dan ikan kerapu yang telah dikembangkan sejak tahun 1990-an adalah wilayah pesisir utara Pulau Bali, khususnya Kecamatan Gerokgak Kabupaten Buleleng Provinsi Bali. Kecamatan Gerokgak memiliki potensi luas lahan untuk budidaya laut sebesar \pm 1.050 ha. Potensi yang baru dimanfaatkan untuk budidaya laut seluas 151,15 ha atau 14,40\% (Dinas Perikanan dan Kelautan Kabupaten Buleleng, 2017). Pada tahun 2017 tercatat 4.709 orang pembudidaya dengan hasil produksi sebanyak 3.314,1 ton yang didominasi oleh hasil tambak, ikan kakap, dan ikan kerapu (Badan Pusat Statistik Kabupaten Buleleng, 2018). Pengembangan budidaya ikan bandeng dan ikan kerapu di perairan pantai dan laut di wilayah pesisir Kecamatan Gerokgak sejauh ini telah memberikan kontribusi berupa pendapatan asli daerah (PAD), kesempatan kerja dan peningkatan pendapatan bagi para pembudidaya dan buruh kerja, serta dampak ganda bagi rantai-rantai usaha yang terkait (Kardi \& Wiasta, 2016). Pembangunan perikanan budidaya (akuakultur) selain menciptakan lapangan kerja juga meningkatkan pendapatan. kegiatan akuakultur kalau tidak dikelola dengan baik dapat berdampak pada pencemaran. Sebagaimana diketahui, sekitar 70\%populasi manusia di Asia Tenggara tinggal di daerah pesisir pantai. Pembangunan industri pertanian, intensifikasi akuakultur, dan urbanisasi yang cepat dan meluas dekat pantai berkontribusi terhadap masalah pencemaran perairan laut (Todd et al., 2010).

Salah satu bioindikator pencemaran adalah keberadaan bakteri patogen dalam perairan yang berasal dari buangan domestik, industri pengolahan limbah, sampah, limbah peternakan, dan perikanan (Parmar et al., 2016). Keberadaan jenis bakteri seperti Coliform, Escherichia coli, Streptococcus spp., Pseudomonas spp., Vibrio spp., Clostridia spp., Bifidobacterium pseudolongum, Arcobacter spp., Thiobacillus spp., dan berbagai bakteri lainnya secara efektif digunakan sebagai indikator polusi untuk mendeteksi kontaminasi tinja, limbah aktivitas manusia, logam berat, limbah pertanian, limbah perikanan, dan minyak mentah (Sumampouw \& Risjani, 2014).

Vibrio spp. merupakan bakteri laut heterotrofik termasuk banyak simbiosis fakultatif dan patogen patologis. Vibrio cholerae, V. parahaemolyticus, dan V. vulnicus dilaporkan sebagai penyebab sebagian besar kasus keracunan makanan laut yang fatal (Collin \& Rehnstam-Holm, 2011). Oleh karena itu, perlu diketahui pola fluktuasi populasi bakteri dan Vibrio spp. di perairan pantai selama satu tahun di sentra pembenihan ikan laut terutama di wilayah perairan yang menjadi tempat pemasukan atau pengambilan air (inlet) untuk usaha pembenihan, dan wilayah pesisir pantai sebagai tempat pembuangan limbah (outlet) dari usaha pembenihan maupun hasil cemaran lainnya. Tujuan dari penelitian ini untuk mengetahui pola fluktuasi populasi bakteri secara umum dan Vibrio spp. secara khusus di perairan pantai dan teluk sebagai dampak dari aktivitas budidaya di pesisir Bali Utara.

\section{BAHAN DAN METODE}

\section{Waktu dan Titik Sampling}

Waktu pengambilan sampel air pada penelitian ini bersamaan dengan pengukuran kualitas air dari penelitian yang telah dilaporkan oleh Mahardika et al. (2018), yaitu dari bulan Februari hingga November tahun 2018 di perairan pantai Kecamatan Gerokgak Kabupaten Buleleng Provinsi Bali. Empat kawasan yang dipilih yaitu dua kawasan dengan aktivitas pembenihan ikan kerapu (Epinephelus spp.), ikan kakap putih (Lates calcarifer), dan ikan bandeng (Chanos chanos) di Desa Gerokgak (Stasiun-A) dan Desa Penyabangan (StasiunB), satu kawasan pembesaran ikan kerapu dan ikan kakap putih dalam karamba jaring apung (KJA) di Teluk Kaping, Desa Sumberkima (Stasiun-C), dan satu lokasi kontrol terletak di perairan Desa Pemuteran (StasiunD) yang merupakan kawasan terumbu karang dan ekowisata laut yang dilindungi.

Titik koordinat sampling ditentukan mengikuti penentuan titik koordinat yang dilaporkan oleh Mahardika et al. (2018), yaitu menggunakan alat Global Positioning System (GPS Garmin 680). Kawasan perairan Stasiun-A dan Stasiun-B merupakan daerah laut terbuka, sehingga sampling dilakukan pada titik perairan sejauh $50 \mathrm{~m}, 100 \mathrm{~m}$, dan $300 \mathrm{~m}$ dari garis 


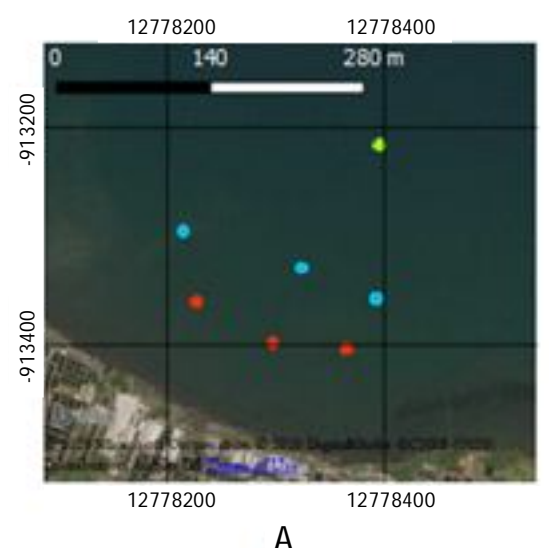

A

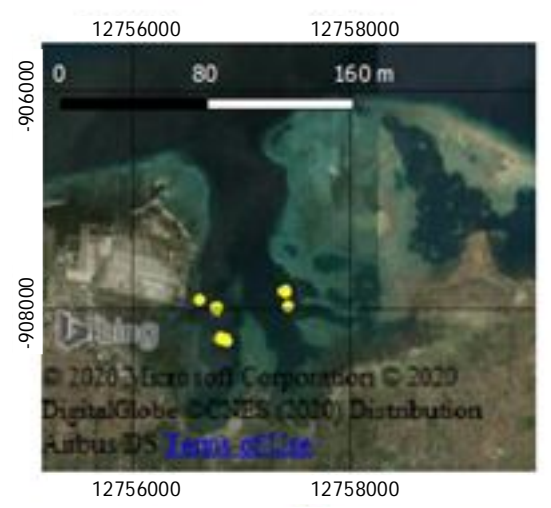

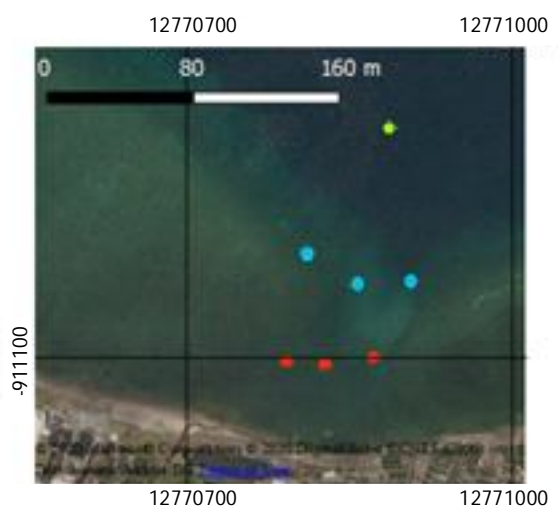

B

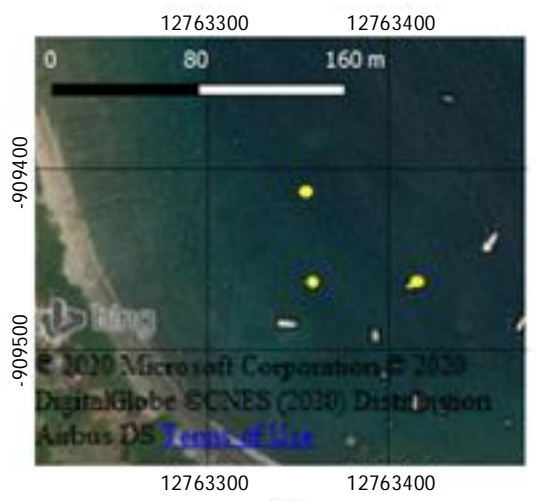

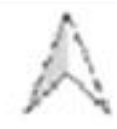

Legend:

A Gerokgak

B Penyabangan

C Teluk Kaping (KapingBay)

D Pemuteran

- 50 meter dari garis pantai

Station $50 \mathrm{~m}$ from coastal line

- 100 meter dari garis pantai

Station $100 \mathrm{~m}$ from coastal line

300 meter dari garis pantai

Station $300 \mathrm{~m}$ from coastal line

Sumber peta (Map source): Bing Aerial

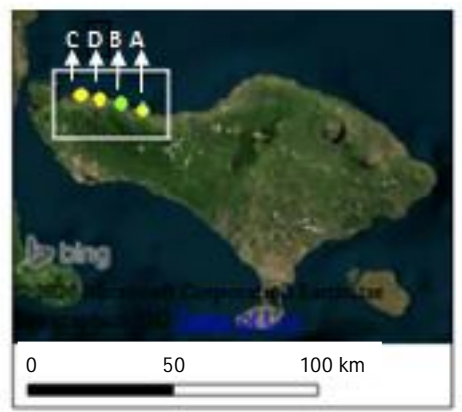

Gambar 1. Lokasi stasiun sampling di sentra budidaya laut di perairan pantai Bali Utara; A). Desa Gerokgak, B). Desa Penyabangan, C). Teluk Kaping (Desa Sumberkima), D) Desa Pemuteran.

Figure 1. Location of sampling stations in the clustered marine fish farm areas of North Bali; A) Gerokgak Village, B) Penyabangan Village, C) Kaping Bay (Sumberkima Village), D) Pemuteran Village.

pantai pada saat pasang tertinggi di lokasi pantai pembenihan ikan laut terpadat (Gambar 1A dan B). Sampling perairan di koordinat sejauh 50 m dilakukan dengan pertimbangan sebagai lokasi outlet (pembuangan limbah) yang dimiliki oleh sebagian besar panti pembenihan. Koordinat sampling sejauh $100 \mathrm{~m}$ dilakukan dengan pertimbangan sebagai lokasi inlet (pengambilan atau pemasukan air) dari sebagian besar panti pembenihan. Sampling air pada koordinat 300 $m$ dilakukan sebagai tambahan titik sampling untuk memperluas area deteksi sebaran dampak air limbah budidaya yang dimulai dari bulan Mei. Stasiun-3 merupakan daerah teluk dengan luasan 595 ha, di mana daerah tersebut memiliki 860 unit KJA yang tersebar hampir di seluruh teluk (Hanafi et al., 2006; Nasukha et al., 2019). Di kawasan ini dilakukan sampling air di tiga titik koordinat (titik 1, 2, dan 3 pada Gambar 1C) sampling yang berada sekitar $1 \mathrm{~m}$ dan $20 \mathrm{~m}$ dari tiga KJA yang sedang beroperasi. Stasiun-D dilakukan sampling pada satu koordinat yaitu titik sejauh $\pm 100 \mathrm{~m}$ dari garis pantai (Gambar 1D).

\section{Sampling Air di Perairan Pantai}

Pengambilan sampel air dilakukan pada tiga titik untuk koordinat $50 \mathrm{~m}$ dan $100 \mathrm{~m}$, dan satu titik untuk koordinat $300 \mathrm{~m}$. Pengambilan sampel air di Teluk Kaping dilakukan pada dua titik untuk masing-masing koordinat sampling (total tiga koordinat) yang berada sekitar $1 \mathrm{~m}$ dan 20 m dari tiga KJA. Sampel air diambil menggunakan tabung kaca steril volume $15 \mathrm{~mL}$ (setelah di-oven pada suhu $150^{\circ} \mathrm{C}$ selama 15 menit) yang dilengkapi dengan tutup plastik yang telah di-autoclave pada suhu $121^{\circ} \mathrm{C}$ selama 15 menit. Tabung kaca tersebut dibawa dalam kondisi dingin menggunakan coolbox yang diisi dengan es. Air permukaan diambil pada kedalaman $\pm 1 \mathrm{~m}$. Masing-masing sampel air pada masing-masing titik koordinat diambil menggunakan tabung kaca berbeda. Tabung kaca dicelupkan ke dalam air laut dengan posisi permukaan atau mulut tabung menghadap ke bawah yang ditutup dengan jari telunjuk. Tabung dibuka pada kedalaman yang ditentukan dan ditutup kembali dengan jari telunjuk sampai ke permukaan air laut, selanjutnya 
ditutup dengan tutup plastik. Tabung kaca yang telah berisi air laut tersebut disimpan dalam coolbox dan dibawa ke Laboratorium Patologi, Balai Besar Riset Perikanan Budidaya Laut dan Penyuluhan Perikanan (BBRBLPP) untuk kultur bakteri.

\section{Sampling Air di Panti Pembenihan}

Sampling air juga dilakukan pada panti pembenihan (hatchery) yang sejajar dengan koordinat pengambilan air pantai (50 m dan $100 \mathrm{~m}$ ). Sampling air di panti pembenihan dilakukan dalam waktu yang bersamaan dengan sampling air di perairan pantai. Sampling ini dilakukan dari bulan Mei sampai bulan November 2018. Sampel air diambil dari bak penampungan (bak reservoir) pada masing-masing tiga panti pembenihan di Desa Gerokgak dan Desa Penyabangan. Air laut diambil menggunakan tabung kaca steril volume $15 \mathrm{~mL}$ dan disimpan dalam coolbox.

\section{Kultur Bakteri}

Kultur bakteri dilakukan dengan mengambil $1 \mathrm{~mL}$ sampel air dengan mikropipet dan diencerkan dalam $9 \mathrm{~mL}$ air laut steril (autoclave pada suhu $121^{\circ} \mathrm{C}$ selama 15 menit) yang telah disiapkan sebelumnya dalam tabung kaca steril volume $15 \mathrm{~mL}$ (pengenceran 10x). Larutan tersebut dihomogenkan dengan fortex selama \pm 10 detik. Sebanyak $100 \mu$ L larutan tersebut dikultur dalam media TSA dalam cawan petri dispossible plastic (tryptic soy agar: $40 \mathrm{~g}$ TSA, $20 \mathrm{~g} \mathrm{NaCl}, 1 \mathrm{~L}$ akuades yang di-autoclave $121^{\circ} \mathrm{C}$ selama 15 menit untuk 20 cawan petri). Kultur bakteri tersebut diinkubasi dalam inkubator pada suhu $30^{\circ} \mathrm{C}$ selama 24 jam. Koloni yang tumbuh dihitung dengan alat colony counter.

Sampel air tersebut juga dikultur dalam media TCBSA dalam cawan petri dispossible plastic (Thiosulfate citrate bile salt sucrose agar: $88 \mathrm{~g}$ TCBSA dalam 1 L akuades yang dipanaskan dalam kompor gas sampai larut merata untuk 20 cawan petri). Sebanyak $100 \mu \mathrm{L}$ sampel air di kultur dalam media TCBSA dan diinkubasi dalam inkubator pada suhu $30^{\circ} \mathrm{C}$ selama 24 jam. Koloni yang tumbuh dihitung dengan alat colony counter.

\section{Analisis Data}

Jumlah koloni (JK) ditentukan dengan menggunakan rumus:

$$
\mathrm{JK}(\mathrm{cfu} / \mathrm{mL})=\mathrm{JK} \text { yang tumbuh dalam media } \times \mathrm{P} \times 10
$$

di mana:

$\mathrm{P}=$ Pengenceran

$P=x 10$ (total bakteri) dan $\mathrm{x} 1$ (Vibrio spp.)

$10=$ jumlah sampel air yang dikultur dalam media $(100 \mu \mathrm{L}$ dijadikan $\mathrm{mL}=\mathrm{x} 10$ )

Jumlah sampel air untuk isolasi bakteri pada titik koordinat $50 \mathrm{~m}$ dan $100 \mathrm{~m}$ adalah masing-masing tiga sampel, sedangkan titik koordinat $300 \mathrm{~m}$ berjumlah satu sampel di setiap lokasi perairan (Gerokgak dan Penyabangan). Pada tiga titik koordinat di KJA diambil masing-masing dua sampel air di setiap titik koordinat. Hasil perhitungan koloni bakteri dirata-ratakan dan ditampilkan dalam bentuk grafik.

\section{Identifikasi Koloni Bakteri yang Dominan}

Dari hasil isolasi yang dilakukan selama 10 bulan sampling ditemukan beberapa bentuk koloni yang dominan tumbuh pada media TSA dan TCBSA. Hasil screening diperoleh tujuh koloni bakteri yang berbeda. DNA bakteri-bakteri tersebut selanjutnya diekstraksi menggunakan kit ekstraksi dan purifikasi (Wizard Promega) sesuai prosedur pemakaian dengan penambahan $50 \mathrm{mM}$ EDTA dan $10 \mathrm{mg} / \mathrm{mL}$ Lysozime. Genom DNA selanjutnya diamplifikasi mengikuti prosedur yang sebelumnya dilaporkan oleh Sudewi et al. (2019). Amplifikasi DNA menggunakan kit GoTag ${ }^{\circledR}$ PCR core system (Promega) dengan sepasang primer 16S rRNA (27F dan 1492R) dengan target amplicon sebesar $1.492 \mathrm{bp}$. Produk PCR dipurifikasi dengan Genomic DNA purification kit (Promega) dan dianalisis sekuensing menggunakan jasa $1^{\text {st }}$ BASE, Singapura. Hasil sekuensing diidentifikasi dalam GenBank database dengan program BLAST (blast.ncbi.nlm.nih.gov/Blast.cgi). Minimal nilai sekuen diidentifikasi homolog dengan spesies bakteri tertentu jika memiliki query cover lebih besar atau sama dengan 97\%(Rungrassamee et al., 2014).

\section{HASIL DAN BAHASAN}

\section{Total Bakteri Permukaan Air Laut}

Hasil sampling air permukaan pantai di Desa Gerokgak menunjukkan bahwa rata-rata total bakteri pada koordinat $50 \mathrm{~m}$ lebih tinggi dibandingkan dengan rata-rata total bakteri pada koordinat $100 \mathrm{~m}$ dan 300 m (Gambar 2A). Total bakteri meningkat pada bulan Februari hingga bulan Mei, dan menurun di bulan selanjutnya hingga pada bulan Oktober terjadi peningkatan kembali. Populasi bakteri tertinggi mencapai $9.067 \pm 7.481 \mathrm{CFU} / \mathrm{mL}$ pada koordinat 50 $\mathrm{m}, 2.233 \pm 587 \mathrm{CFU} / \mathrm{mL}$ pada koordinat $100 \mathrm{~m}$ dan $200 \mathrm{CFU} / \mathrm{mL}$ pada koordinat $300 \mathrm{~m}$. Total bakteri terendah terjadi di bulan Juli pada koordinat $100 \mathrm{~m}$ hingga $733 \pm 306 \mathrm{CFU} / \mathrm{mL}$, pada bulan Agustus pada koordinat $50 \mathrm{~m}$ mencapai $427 \pm 156 \mathrm{CFU} / \mathrm{mL}$, dan di bulan September pada koo rdinat $300 \mathrm{~m}$ hingga 60 CFU/ $\mathrm{mL}$.

Total bakteri air permukaan pantai Desa Penyabangan menunjukkan jumlah yang lebih rendah dibandingkan dengan total bakteri di perairan pantai Desa Gerokgak (Gambar 2B). Pola peningkatan total bakteri yang sama ditunjukkan pada semua koordinat 

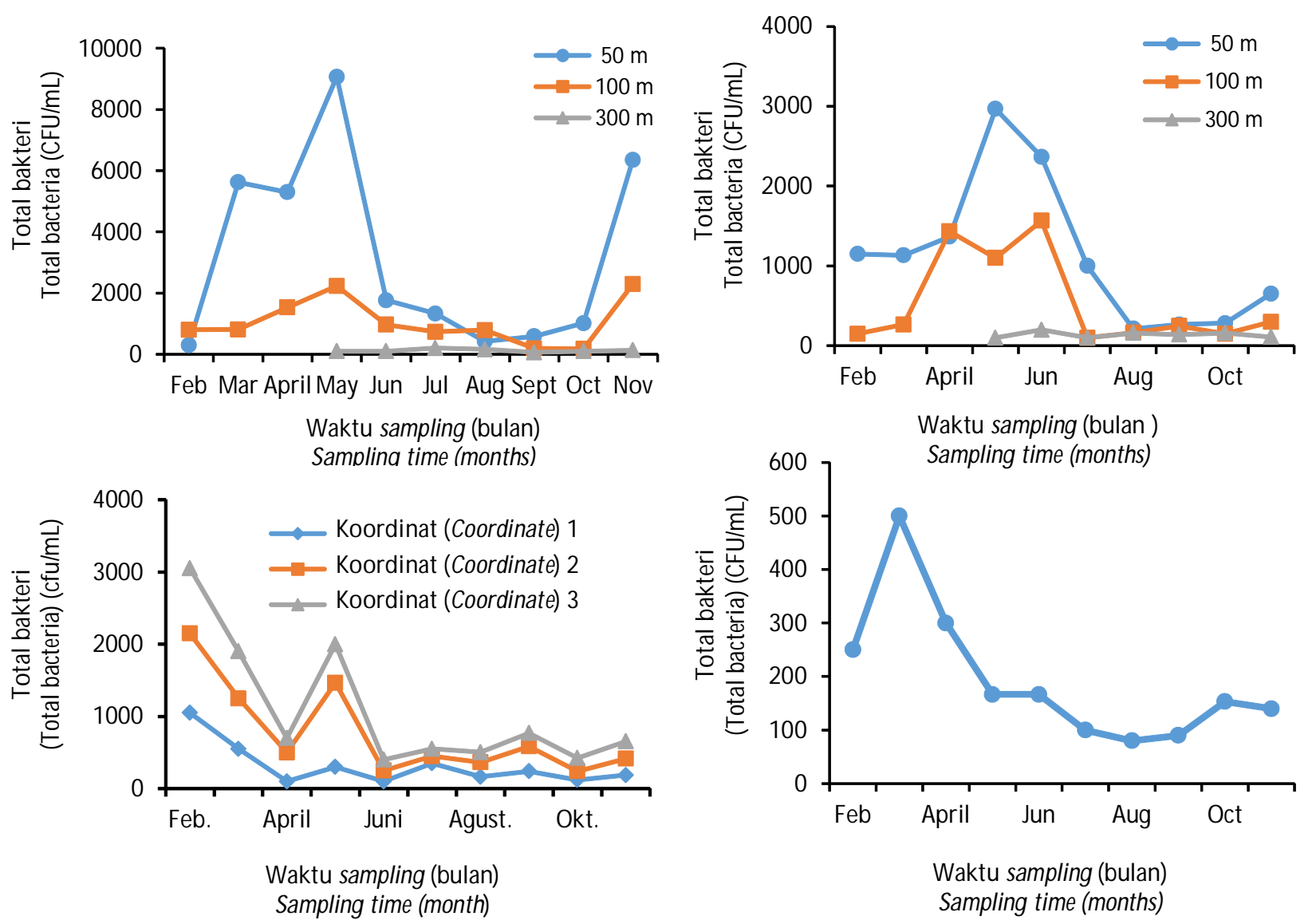

Gambar 2. Pola total bakteri selama bulan Februari hingga November 2018 di keempat stasiun sampling; Desa Gerokgak (A), Desa Penyabangan (B), Teluk Kaping (C), dan Desa Pemuteran (D).

Figure 2. Variation of total bacteria from February to November 2018 in four sampling sites: Gerokgak Village (A), Penyabangan Village (B), Kaping Bay (C), and Pemuteran Village (D).

antara Desa Gerokgak dan Desa Penyabangan. Total bakteri koodinat $50 \mathrm{~m}$ lebih tinggi dibandingkan dengan koordinat $100 \mathrm{~m}$ dan $300 \mathrm{~m}$. Total bakteri tertinggi pada koordinat 50 m mencapai $2.967 \pm 764$ $\mathrm{CFU} / \mathrm{mL}$, sedangkan total bakteri tertinggi pada koordinat $100 \mathrm{~m}$ dan $300 \mathrm{~m}$ terjadi di bulan Juni yaitu $1.567 \pm 306 \mathrm{CFU} / \mathrm{mL}$ dan $200 \mathrm{CFU} / \mathrm{mL}$. Total bakteri terendah terjadi pada bulan Juli pada koordinat $100 \mathrm{~m}$ dan $300 \mathrm{~m}$ yaitu $100 \pm 0 \mathrm{CFU} / \mathrm{mL}$, sedangkan populasi bakteri terendah pada koordinat $50 \mathrm{~m}$ terjadi pada bulan Agustus yaitu $213 \pm 84 \mathrm{CFU} / \mathrm{mL}$.

Total bakteri pada tiga koordinat di perairan Teluk Kaping memiliki kisaran nilai yang sama dengan koordinat $100 \mathrm{~m}$ pada perairan pantai di sentra pembenihan ikan laut di Desa Gerokgak dan Desa Penyabangan (Gambar 2C). Pola peningkatan total bakteri perairan di Teluk Kaping sama dengan pola total bakteri perairan di dua desa sebelumnya yaitu tinggi di bulan Februari sampai Mei, dan menurun di bulan Juni sampai akhir sampling (bulan November) dengan jumlah sedikit berfluktuasi. Total bakteri tertinggi terjadi di bulan Mei hingga $1.167 \pm 231$
CFU/mL dan terendah hingga populasi $120 \pm 14$ CFU/ $\mathrm{mL}$ di bulan Oktober. Total bakteri di perairan yang berjarak 100 m dari garis pantai di Desa Pemuteran memiliki kisaran total bakteri sama dengan kisaran total bakteri perairan pada koordinat $300 \mathrm{~m}$ di Desa Gerokgak dan Desa Penyabangan (Gambar 2D). Pola peningkatan total bakteri mengikuti pola peningkatan total bakteri di ketiga lokasi sentra budidaya ikan laut. Total bakteri tertinggi terjadi pada bulan Maret yang mencapai $500 \pm 52 \mathrm{CFU} / \mathrm{mL}$, dan terendah mencapai $80 \pm 27 \mathrm{CFU} / \mathrm{mL}$.

Konsentrasi amonia di Teluk Kaping dilaporkan lebih tinggi dibandingkan konsentrasi amonia di perairan pantai Desa Gerokgak dan Desa Penyabangan (Nasukha et al., 2019), namun total bakteri permukaan di tiga koordinat lebih rendah dibandingkan dengan total bakteri di perairan pantai pada titik koordinat $50 \mathrm{~m}$ di dua desa tersebut. Hal tersebut kemungkinan disebabkan karena ketiga titik koordinat tersebut berada pada perairan yang lebih dalam (>15 m) dibandingkan dengan koordinat $5 \mathrm{~m}$ (kedalaman $<5$ $\mathrm{m})$ dari garis pantai. Walaupun diduga bahwa kondisi 
kegiatan budidaya yang padat di Teluk Kaping dengan 830 petak KJA per luasan 595 ha menjadi pemicu jenuhnya kadar bahan organik di perairan (Sutarmat et al., 2014; Nasukha et al., 2019), namun beban limbah padat yang kemungkinan mengendap di dasar perairan dengan kondisi air yang relatif tenang tidak menimbulkan dampak yang signifikan terhadap populasi bakteri permukaan air.

Total bakteri yang terdata di Desa Pemuteran kemungkinan merupakan dampak dari usaha budidaya perikanan. Sebaran limbah budidaya kemungkinan juga berdampak sampai ke perairan pesisir pantai Desa Pemuteran, mengingat wilayah tersebut berada di antara Teluk Kaping dan Desa Penyabangan yang disinyalir berpengaruh terhadap fluktuasi total bakteri di perairan Desa Pemuteran (Nasukha et al., 2019).

\section{Vibrio spp. Permukaan Air Laut}

Secara umum, fluktuasi populasi Vibrio spp. di keempat lokasi sampling memiliki pola yang sama dengan total bakteri (Gambar 3).

Populasi Vibrio spp. pada perairan pantai Desa Gerokgak di koordinat 50 m (Gambar 3A) terdata lebih tinggi dibandingkan dengan populasi Vibrio spp. di koordinat $100 \mathrm{~m}$ dan $300 \mathrm{~m}$. Populasi Vibrio spp. pada koordinat $50 \mathrm{~m}$ dan $100 \mathrm{~m}$ meningkat di bulan Maret dan mencapai puncaknya di bulan Mei hingga $1.147 \pm$ $689 \mathrm{CFU} / \mathrm{mL}$ dan $530 \pm 235 \mathrm{CFU} / \mathrm{mL}$. Populasi Vibrio spp. tersebut menurun di bulan Juni hingga mencapai populasi terendah pada bulan Agustus yaitu $47 \pm 15$ $\mathrm{CFU} / \mathrm{mL}$ pada koordinat $50 \mathrm{~m}$ dan $30 \pm 20 \mathrm{CFU} / \mathrm{mL}$ pada koordinat $100 \mathrm{~mL}$. Populasi Vibrio spp. teramati meningkat kembali pada bulan November. Vibrio spp. pada koordinat $300 \mathrm{~m}$ teramati dengan populasi tertinggi mencapai $60 \mathrm{CFU} / \mathrm{mL}$ dan terendah hingga 0 $\mathrm{CFU} / \mathrm{mL}$.

Populasi Vibrio spp. di perairan pantai Desa Penyabangan teramati lebih rendah (Gambar 3B) dibandingkan dengan populasi Vibrio spp. di perairan pantai Desa Gerokgak. Populasi Vibrio spp. terilhat meningkat di bulan Februari hingga mencapai puncaknya di bulan Maret pada koordinat 50 m sebesar $348 \pm 100 \mathrm{CFU} / \mathrm{mL}$, dan di bulan April pada koordinat $100 \mathrm{~m}$ sebesar $450 \pm 70 \mathrm{CFU} / \mathrm{mL}$. Selanjutnya populasi Vibrio spp. menurun dengan nilai terendah di bulan Juli (koordinat $100 \mathrm{~m}$ ) dan bulan Agustus (koordinat
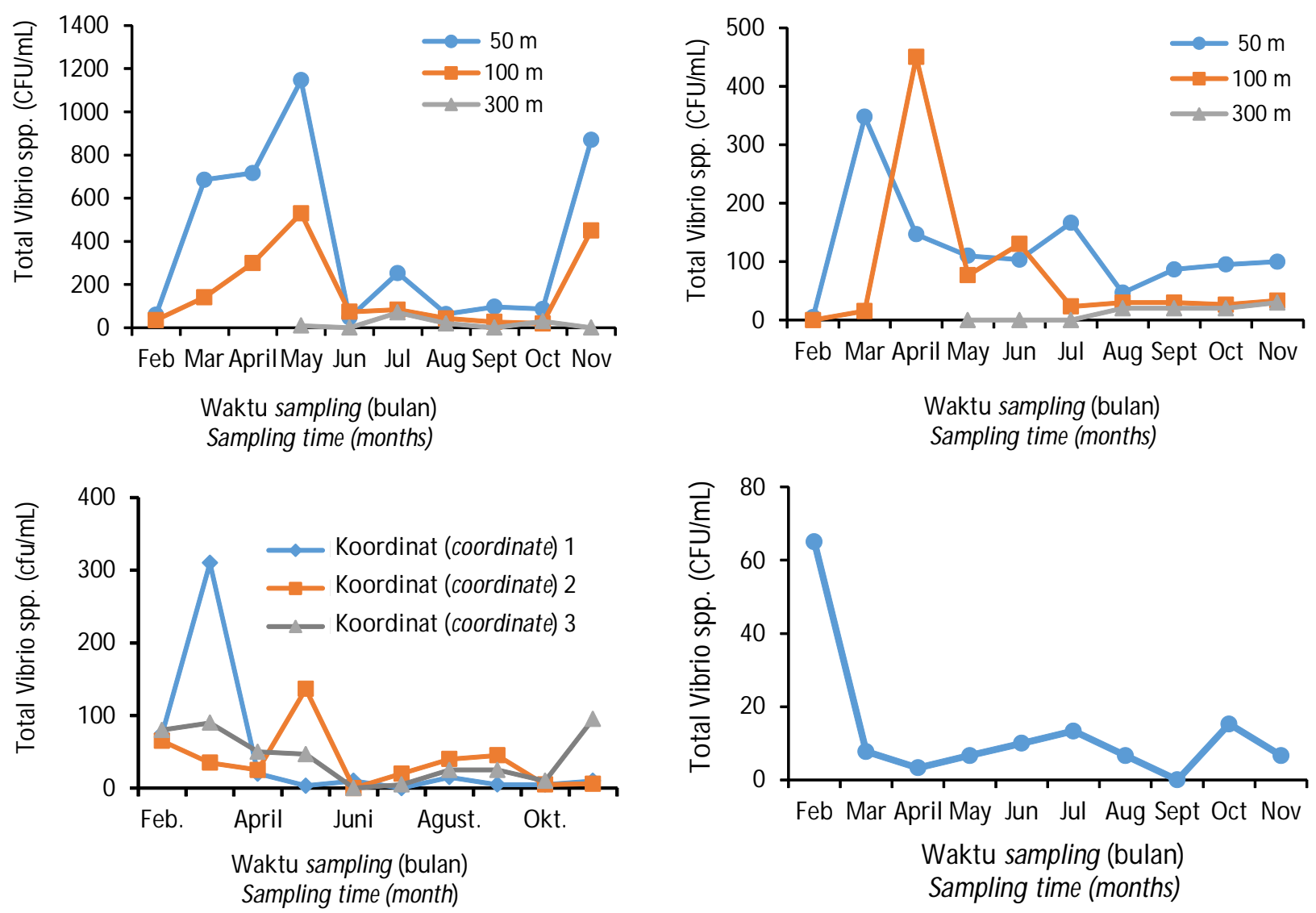

Gambar 3. Fluktuasi Vibrio spp. selama bulan Februari hingga November 2018 di keempat stasiun sampling; Desa Gerokgak (A), Desa Penyabangan (B), Teluk Kaping (C), dan Desa Pemuteran (D).

Figure 3. Fluctuation of Vibrio spp. from February to November 2018 in four sampling sites: Gerokgak Village (A), Penyabangan Village (B), Kaping Bay (C), and Pemuteran Village (D). 
$50 \mathrm{~m}$ ) sebesar $23 \pm 15 \mathrm{CFU} / \mathrm{mL}$ dan $47 \pm 15 \mathrm{CFU} / \mathrm{mL}$. Populasi Vibrio spp. tersebut mengalami kenaikan kembali di bulan September. Populasi Vibrio spp. pada koordinat $300 \mathrm{~m}$ menunjukkan nilai tertinggi hingga $30 \mathrm{CFU} / \mathrm{mL}$ dan terendah sebesar $20 \mathrm{CFU} / \mathrm{mL}$.

Fluktuasi populasi Vibrio spp. di perairan Teluk Kaping (Gambar 3C) menunjukkan pola yang sama dengan fluktuasi populasi Vibrio spp. di perairan pantai lainnya. Populasi Vibrio spp. tertinggi teramati pada koordinat-1 hingga $310 \pm 141 \mathrm{CFU} / \mathrm{mL}$ (bulan Maret) diikuti oleh koordinat-2 dan 3 masing-masing $137 \pm$ $74 \mathrm{CFU} / \mathrm{mL}$ dan $47 \pm 31 \mathrm{CFU} / \mathrm{mL}$ di bulan Mei. Populasi Vibrio spp. juga teramati di perairan pantai Desa Pemuteran (Gambar 3D) dengan pola fluktuasi yang sama dengan ketiga perairan di atas. Populasi Vibrio spp. tertinggi terdata di bulan Maret mencapai $65 \pm$ $7 \mathrm{CFU} / \mathrm{mL}$.

Secara umum, total bakteri dan Vibrio spp. di keempat lokasi sampling terlihat memiliki pola yang konsisten. Pola fluktuasi total bakteri dan Vibrio spp. tersebut mengikuti musim yang memengaruhi pola pergerakan suhu. Menurut Koji et al. (2015), musim dapat memengaruhi populasi bakteri pada permukaan air. Selama musim hujan dilaporkan terjadi peningkatan populasi bakteri Vibrio spp. dan Aeromonas spp. yang menempel di permukaan kopepoda. Berdasarkan rata-rata curah hujan dari Badan Pusat Statistik Kabupaten Buleleng (2017) menunjukkan bahwa curah hujan tertinggi tejadi di awal tahun (bulan Januari-Juni) dan di akhir tahun (bulan NovemberDesember). Musim hujan di tahun tersebut hampir sama dengan musim hujan pada tahun 2018. Pada musim hujan di perairan Bali Utara di tahun 2018 dilaporkan terjadi peningkatan suhu di pertengahan bulan Januari $\left(28,20 \pm 0,84^{\circ} \mathrm{C}\right)$ hingga bulan April $\left(30,10 \pm 1,01^{\circ} \mathrm{C}\right)$. Suhu perairan pantai selanjutnya mengalami penurunan pada peralihan musim hujan ke musim kemarau dengan nilai terendah di bulan Agustus $\left(28,22 \pm 0,36^{\circ} \mathrm{C}\right)$. Aliran udara yang dingin di Kecamatan Gerokgak pada kurun waktu peralihan musim hujan ke musim kemarau kemungkinan memengaruhi suhu perairan pantai. Pada akhir bulan Agustus terjadi pengulangan pola kenaikan suhu hingga bulan Desember (Nasukha et al., 2019); di mana waktu tersebut merupakan peralihan musim panas ke hujan. Joint \& Smale (2017) melaporkan bahwa suhu memengaruhi aktivitas bakteri, di mana aktivitas mikroba maksimum terjadi pada suhu tinggi. Frekuensi dan besarnya gelombang panas laut cenderung meningkat dan dapat memengaruhi peran kumpulan bakteri dalam proses biogeokimia. Peningkatan suhu air juga memengaruhi proses nitrifikasi, di mana amonia dioksidasi menjadi nitrit $\left(\mathrm{NO}_{2}\right)$ yang selanjutnya dioksidasi menjadi nitrat $\left(\mathrm{NO}_{3}\right)$.
Langkah oksidasi pertama dimediasi oleh bakteri pengoksidasi amonia (AOB), sedangkan langkah kedua dimediasi oleh bakteri pengoksidasi nitrit. Dalam siklus nitrogen, nitrifikasi menghubungkan mineralisasi $\mathrm{N}$ dengan denitrifikasi yang menghasilkan gas $\mathrm{N}_{2}$ (Chen et al., 2010; Isnansetyo et al., 2014). Nitrogen merupakan unsur yang paling berpengaruh dalam meningkatkan pengayaan bahan organik dan memicu adanya eutrofikasi pada perairan pantai (Howarth \& Marino, 2006). Peningkatan konsentrasi karbon organik terlarut dilaporkan memiliki korelasi yang signifikan terhadap populasi bakteri di perairan pantai (Wang et al., 2017).

Populasi Vibrio spp. di perairan pantai Desa Gerokgak teramati lebih tinggi dibandingkan dengan perairan pantai dan teluk lainnya. Hal tersebut kemungkinan disebabkan adanya alih fungsi lahan, lokasi pembenihan yang mengelompok dalam satu area/lokasi dan kondisi, serta manajemen beberapa pembenihan yang masih kurang baik sehingga berdampak terhadap peningkatan cemaran limbah bahan organik dan anorganik di perairan pantai tersebut. Hal tersebut berbeda dengan kondisi perairan pantai Desa Penyabangan yang terlihat lebih jernih dengan lokasi pembenihan lebih menyebar dan merata sepanjang pantai, dan manajemen pembenihan yang lebih baik (Mahardika et al., 2019). Dampak dari alih fungsi dan kondisi pembenihan tersebut juga dilaporkan kemungkinan berpengaruh terhadap populasi bakteri dalam substrat pantai seperti total bakteri, Vibrio spp., Enterobacter spp., bakteri halotoleran, dan bakteri mikrofilik anaerob. Populasi bakteri substrat pantai Desa Gerokgak teramati lebih tinggi dibandingkan dengan substrat pantai Desa Penyabangan sepanjang tahun 2018-2019 (Mahardika et al., 2018; 2019).

\section{Total Bakteri dan Vibrio spp. pada Bak Penampungan Air di Panti Pembenihan}

Pola fluktuasi total bakteri dan Vibrio spp. air laut di bak penampungan pada unit pembenihan di Desa Gerokgak dan Desa Penyabangan mengikuti pola fluktuasi bakteri air laut (Gambar 4A dan B). Populasi total bakteri di kedua desa tersebut hampir sama yaitu populasi tertinggi terdata di bulan Mei hingga 9.133 $\pm 1.222 \mathrm{CFU} / \mathrm{mL}$ dan $8.500 \pm 1.202 \mathrm{CFU} / \mathrm{mL}$, dan terendah di bulan September mencapai $17 \pm 6$ CFU/ $\mathrm{mL}$ dan $86 \pm 23 \mathrm{CFU} / \mathrm{mL}$. Vibrio spp. mengalami fase tinggi pada bulan Mei-Juni dan Oktober-November yaitu $33 \pm 6-53 \pm 15 \mathrm{CFU} / \mathrm{mL}$ dan $47 \pm 15-63 \pm 31$ $\mathrm{CFU} / \mathrm{mL}$. Pola fluktuasi populasi bakteri pada air budidaya memengaruhi populasi bakteri pada ikan budidaya. Menurut Kim \& Lee (2017), tingkat populasi bakteri dan Vibrio spp. pada ikan berbanding lurus 
dengan tingkat populasi bakteri dan Vibrio spp. dalam air budidaya. Oleh karena itu, pengawasan kepadatan Vibrio spp. pada perairan budidaya dapat menjadi salah satu indikator adanya kontaminasi mikroba padaikan. Hal tersebut juga dibuktikan dengan ditemukannya kepadatan bakteri dengan konsentrasi tinggi $\left(10^{7}-10^{8}\right.$ CFU/g) pada organ hati ikan kerapu dan kakap putih yang dipelihara di unit pembenihan di bulan Februari, April, sampai Juli. Pola tersebut diikuti pula dengan populasi Vibrio spp. dalam tubuh ikan yang mana populasi tinggi $\left(10^{4}-10^{6} \mathrm{CFU} / \mathrm{g}\right)$ dan sangat tinggi $\left(10^{7}\right.$ $10^{9} \mathrm{CFU} / \mathrm{g}$ ) terjadi di bulan Maret, April, dan Juni (Mahardika et al., 2020). Lebih jauh dilaporkan bahwa tingginya populasi bakteri pada organ dalam ikan memicu terjadinya infeksi virus VNN yang menimbulkan kematian massal benih ikan kerapu dan ikan kakap putih di panti pembenihan. Di mana prevalensi infeksi virus VNN banyak terjadi di bulan Maret sampai Juli dan meningkat pada bulan November.

\section{Bakteri Dominan pada Perairan Pantai di Sentra Budidaya Ikan Laut di Kecamatan Gerokgak}

Hasil sekuensing isolat bakteri yang ditemukan di perairan pantai di sentra budidaya ikan laut di Kecamatan Gerokgak seperti pada Tabel 1.

Tabel 1 menunjukkan bahwa hasil sekuensing dari koloni bakteri yang diperoleh selama 10 bulan pemantauan perairan pantai di Kecamatan Gerokgak adalah Bacillus cereus, Vibrio alginolyticus, V. harveyi, V. parahaemolyticus, dan Staphylococcus sciuri. Bakteri Vibrio spp. merupakan bakteri yang ditemukan secara alami di perairan laut dan muara. Beberapa Vibrio spp. ditemukan pada air laut hingga air payau dengan kelimpahan populasi tunggal berkisar dari $5 \times 10^{2}$ hingga $7 \times 10^{4} \mathrm{sel} / \mathrm{L}$ (Eiler et al., 2006). Menurut Caburlotto et al. (2012) dan Böer et al. (2013), suhu dan salinitas merupakan dua parameter lingkungan yang sangat berpengaruh terhadap populasi Vibrio spp. Lebih jauh dilaporkan bahwa Vibrio spp. dalam sedimen atau substrat pantai memiliki populasi lebih tinggi dari pada air. Vibrio. harveyi merupakan jenis Vibrio spp. yang paling patogen pada ikan kakap putih dan ikan kerapu (Rangsangan et al., 2012). Lebih jauh dilaporkan bahwa V. harveyi yang menyerang ikan kakap putih dan ikan kerapu memiliki perbedaan gen hemolisin dengan $\mathrm{V}$. harveyi yang menyerang udang windu (Penaeus monodon). V. vulniûcus dan V. parahaemolyticus juga dilaporkan sebagai penyebab utama penyakit bakteri dari produk makanan laut (Baker-Austin et al., 2010). Bacillus cereus ditemukan di perairan pantai kemungkinan berasal dari tambak udang dan panti pembenihan ikan kerapu. B. cereusini banyak digunakan sebagai probiotik untuk budidaya udang dan ikan kerapu (Nurhidayu et al., 2012; Buruianã et al., 2014). Staphylococcus spp. memiliki berbagai aktivitas degradatif dan dapat berkontribusi pada detoksifikasi limbah dan daur ulang nutrisi di laut. Spesies dari Staphylococcus spp. yang ditemukan di perairan pantai hingga muara seperti S. hominis, S. Epidermidis, dan S. sciuri (Gunn \& Colwell, 1983).

Bakteri Vibrio spp. dapat berperan sebagai patogen primer ataupun patogen sekunder. Sebagai patogen primer, Vibrio spp. masuk melalui kontak langsung dengan organisme, sedangkan sebagai patogen sekunder, Vibrio spp. menginfeksi organisme yang telah terlebih dahulu terinfeksi penyakit lain (Ayini et
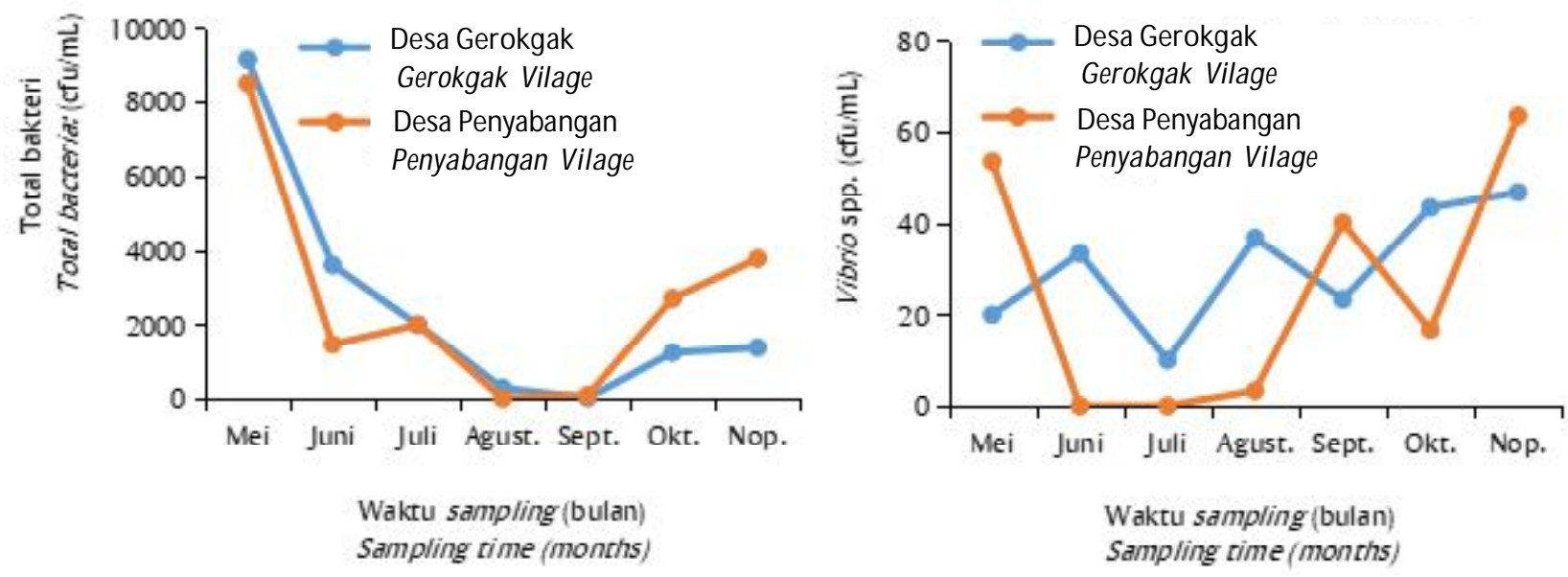

Gambar 4. Fluktuasi total bakteri dan Vibrio spp. selama bulan Mei hingga November 2018 pada bak penampungan air di panti pembenihan; Desa Gerokgak (A) dan Desa Penyabangan (B).

Figure 4. Variations of total bacteria and Vibrio spp. from May to November 2018 in reservoir tanks of different hatcheries: Gerokgak Village (A) and Penyabangan Village (B). 
Tabel 1. Spesies bakteri yang ditemukan pada perairan laut di sentra budidaya ikan laut, Kecamatan Gerokgak tahun 2018

Table 1. Species of bacteria found in the sampling locations of Gerokgak coastal waters in 2018

\begin{tabular}{|c|c|c|c|}
\hline $\begin{array}{l}\text { Identitas isolat } \\
\text { Isolate ID }\end{array}$ & $\begin{array}{l}\text { Spesies terdekat } \\
\text { Closest species }\end{array}$ & $\begin{array}{c}\text { Nomor akses } \\
\text { database } \\
\text { Database accession } \\
\text { number }\end{array}$ & $\begin{array}{l}\text { Kemiripan sekuen } \\
\text { Similarity: maximal } \\
\text { scoreltotal score- } \\
\text { (Query cover/Per Ident) }\end{array}$ \\
\hline Ks_ALk_ 6 & $\begin{array}{l}\text { Bacillus cereus strain D21 16S } \\
\text { rRNA gene._partial sequence }\end{array}$ & KC441762.1 & $\begin{array}{l}2597 / 2597 \\
(98 \% / 999,51 \%)\end{array}$ \\
\hline PaK_ALk_7 & $\begin{array}{l}\text { Vibrio alginolyticus strain CHN-17 16S } \\
\text { rRNA gene._partial sequence }\end{array}$ & KR347188.1 & $\begin{array}{l}2586 / 2586 \\
(98 \% / 99.37 \%\end{array}$ \\
\hline Km_ALk-13 & $\begin{array}{l}\text { Vibrio harveyi strain HH101315 16S } \\
\text { rRNA gene._partial sequence }\end{array}$ & KF746885.1 & $\begin{array}{l}2573 / 2573 \\
(99 \% 98.96 \%)\end{array}$ \\
\hline Ks_ALk_14 & $\begin{array}{l}\text { Bacillus cereus strain D21 16S } \\
\text { rRNA gene._partial sequence }\end{array}$ & KC441762.1 & $\begin{array}{l}2597 / 2597 \\
(98 \% 99.51 \%)\end{array}$ \\
\hline Ps_ALk_21 & $\begin{array}{l}\text { Staphylococcus sciuri strain DZ-T1 16S } \\
\text { rRNA gene._partial sequence }\end{array}$ & KRA476410.1 & $\begin{array}{l}2649 / 2649 \\
(99 \% / 99.52 \%)\end{array}$ \\
\hline Kb_ALk_52 & $\begin{array}{l}\text { Vibrio parahaemolyticus strain Vp-4 } 16 S \\
\text { rRNA gene._partial sequence }\end{array}$ & MK377081.1 & $\begin{array}{l}2584 / 2584 \\
(99 \% / 98.90 \%)\end{array}$ \\
\hline Ks_ALk_60-9 & $\begin{array}{c}\text { Vibrio parahaemolyticus strain Vp-4 } 165 \\
\text { rNA gene._partial sequence }\end{array}$ & MK377081.1 & $\begin{array}{l}2547 / 2547 \\
(99 \% / 98.41 \%\end{array}$ \\
\hline
\end{tabular}

al., 2014). Populasi total bakteri dan Vibrio spp. di perairan pantai Desa Gerokgak, Desa Penyabangan, Desa Pemuteran, dan Teluk Kaping masih dalam batas normal sesuai dengan standar Laboratorium Patologi, Balai Besar Riset Budidaya Laut dan Penyuluhan Perikanan, Gondol, Bali yang telah terakreditasi (ISO/ IEC 17025:2017) yaitu total bakteri berkisar antara $10^{3}-10^{6} \mathrm{CFU} / \mathrm{mL}$ dan Vibrio spp. berkisar antara $10^{2}-10^{3}$ $\mathrm{CFU} / \mathrm{mL}$.

\section{KESIMPULAN}

Populasi bakteri dan Vibrio spp. di beberapa lokasi yang berbeda di Bali Utara menunjukkan bahwa fluktuasinya dipengaruhi oleh musim dan keberadaan panti pembenihan, serta karamba jaring apung di lokasi-lokasi tersebut. Total bakteri dan Vibrio spp. di tiga lokasi perairan di sentra budidaya laut di Kecamatan Gerokgak, Bali menunjukkan populasi tinggi di bulan Maret hingga Mei dan di bulan Oktober hingga November. Fluktuasi populasi bakteri ini erat hubungannya dengan peralihan musim (musim hujan ke musim kemarau atau sebaliknya). Oleh karena itu, pembudidaya ikan laut perlu melakukan perbaikan manajemen budidaya yang lebih baik. Salah satunya adalah menyesuaikan tahapan budidaya/siklus hidup ikan budidaya yang rentan dengan populasi Vibrio spp. yang tinggi untuk menghindari terjadinya penyakit pada ikan budidaya tersebut.

\section{UCAPAN TERIMA KASIH}

Penelitian ini dibiayai oleh APBN Balai Besar Budidaya Laut dan Penyuluhan Perikanan (BBRBLPP) DIPA Tahun 2018. Penulis mengucapkan terima kasih kepada bapak Prof. Dr. Ketut Sugama, M.S. atas saran dan masukan dalam tulisan ini, serta teknisi litkayasa pada Laboratorium Patologi, Laboratorium Kimia, dan Laboratorium Lingkungan BBRBLPP, Gondol yang telah membantu dalam pelaksanaan penelitian ini.

\section{DAFTAR ACUAN}

Ayini, U., Harnina, S.B., \& Dewi, T.C. (2014). Efek antibakteri ekstrak daun mimba (Azadirachta indica A. Juss) terhadap bakteri Vibrio algynoliticus secara In Vitro. Biosaintifika, 6(1), 67-75.

Badan Pusat Statistik Kabupaten Buleleng. (2017). Ratarata curah hujan dan hari hujan di Kabupaten Buleleng menurut bulan. Update terakhir 01 Oktober 2018. https://bulelengkab.bps.go.id/ statictable/2015/03/16/32/rata-rata-curah-hujan-danhari-hujan-di-kabupaten-buleleng-menurut-bulan2017.html. Diakses 14 Juni 2020.

Badan Pusat Statistik Kabupaten Buleleng. (2018). Statistik Daerah. Pemerintah Kabupaten Buleleng, 75 hlm. www. statistik.bulelengkab.go.id.

Baker-Austin, C., Stockley, L., Rangdale, R., \& Martinez-Urtaza, J. (2010). Environmental 
occurrence and clinical impact of Vibrio vulniûcus and Vibrio parahaemolyticus: A European perspective. Environmental Microbiology Reports, 2(1), 7-18.

Böer, S.I., Heinemeyer, E-A., Luden, K., Erler, R., Gerdts, G., Janssen, F., \& Brennholt, N. (2013). Temporal and spatial distribution patterns of potentially pathogenic Vibrio spp. at recreational beaches of the German North Sea. Microb. Ecol., 65, 1052-1067.

Buruianã, C.-T., Profir, A.G., \& Vizireanu, C. (2014). Effects of probiotic bacillus species in aquaculture-an overview. AUDJG-Food Technology, $38(2), 9-17$.

Caburlotto, G., Bianchi, F., Gennari, M., Ghidini, V., Socal, G., Aubry, F.B., Bastianini, M., Tafi, M.C., \& Lleo. M.M. (2012). Integrated evaluation of environmental parameters influencing Vibrio occurrence in the coastal Northern Adriatic Sea (Italy) facing the Venetian Lagoon. Microb. Ecol., 63, 20-31.

Chen, G., Cao, X., Song, C., \& Zhou, Y. (2010). Adverse effects of ammonia on nitrification process: The case of Chinese Shallow Freshwater Lakes. Water Air Soil Pollut., 210, 297-306.

Collin, B. \& Rehnstam-Holm, A-S'. (2011). Occurrence and potential pathogenesis of Vibrio cholerae, Vibrio parahaemolyticus, and Vibrio vulniccus on the South Coast of Sweden. FEM S Microbiology Ecology, 78, 306-313.

Dinas Perikanan dan Kelautan Kabupaten Buleleng. (2017). Laporan akuntabilitas kinerja instansi pemerintah (LAKIP) tahun 2016. Pemerintah Kabupaten Buleleng. $27 \mathrm{hlm}$. https:// bulelengkab.go.id > bankdata.

Eiler, A., Johansson, M., \& Bertilsson, S. (2006). Environmental inûuences on Vibrio populations in Northern Temperate and Boreal Coastal Waters (Baltic and Skagerrak Seas). Applied and Environmental Microbiology, 72(9), 6004-6011.

Gunn, B.A. \& Colwell, R.R. (1983). Numerical taxonomy of staphylococci isolated from the marine environment. International Journal of Systematic Bacteriology, 33(4), 751-759.

Hanafi, A., Andriyanto, W., Syahidah, D., \& Sukresno, B. (2006). Characteristic and carrying capacity of Kaping Bay, Buleleng Regency, Bali for marine aquaculture development. Prosiding Kajian Keragaan dan Pemanfaatan Perikanan Budidaya, hlm. 83-95.

Howarth, R.W. \& Marino, R. (2006). Nitrogen as the limiting nutrient for Eutrophication in coastal marine ecosystems: Evolving views over three decades. Limnol. Oceanography, 51(1 part 2), 164-376.

Isnansetyo, A., Getsu, S., Seguchi, M., \& Koriyama, M. (2014). Independent effects of temperature, salinity, ammonium concentration and $\mathrm{pH}$ on nitrification rate of the Ariake seawater above mud sediment. Hayati Journal of Biosciences, 21(1), 21-30.

Joint, I. \& Smale, D.A. (2017). Marine heatwaves and optimal temperatures for microbial assemblage activity. FEM S M icrobiology Ecology, 93(2), 1-9.

Kardi, C. \& Wiasta, I W. (2016). Pengembangan agrowisata budidaya perikanan laut berbasis masyarakat pesisir di Kecamatan Gerokgak. Prosiding Seminar Nasional. Hasil Penelitian dan Pengabdian Kepada Masyarakat. Lembaga Penelitian dan Pemberdayaan Masyarakat (LPPM) Unmas Denpasar, hlm. 911-924.

Kim, J.Y. \& Lee, J.-L. (2017). Correlation of total bacterial and Vibrio spp. populations between fish and water in the aquaculture system. Frontiers in Marine Science, 4, article 147, 1-10.

Koji, E., Arfao, A.T., Djimeli, C.L., Ewoti, O.V.N., Nougang, M.E., Bricheux, G., Nola, M., \& SimeNgando, T. (2015), Impact of rainfall and some water abiotic factors on the abundance dynamic of vibrio and aeromonas adhered to copepods surface in some coastal streams and rivers in Cameroon (Central Africa). International Journal of Research Studies in Biosciences, 3(9), 11-21.

Mahardika, K., Zafran, Roza, D., Mastuti, I., Syahidah, D., Nasukha, A., Septory, R., Sudewi, Astuti, N.W.W., Ismi, S., \& Setiadi, A. (2018). Pemantauan lingkungan dan kejadian penyakit di kawasan budidaya laut, Bali Utara. Laporan Teknis Balai Besar Riset Budidaya Laut dan Penyuluhan Perikanan, Gondol, Bali, $39 \mathrm{hlm}$.

Mahardika, K., Zafran, Septori, R., Nasukha, A., Mastuti, I., Syahidah, D., Ismi, S., Supii, A.I., Setiadi, A., \& Sudewi. (2019). Aplikasi vaksin polivalen pada ikan kerapu di keramba jaring apung dan pemantauan vertikal kualitas air lingkungan perairan dan kejadian penyakit di kawasan budidaya laut di Bali Utara. Laporan Teknis Balai Besar Riset Budidaya Laut dan Penyuluhan Perikanan, Gondol, Bali, $43 \mathrm{hlm}$.

Mahardika, K., Mastuti, I., Roza, D., Syahidah, D., Astuti, N.W.W., Ismi S., \& Zafran (2020). Pemantauan insidensi penyakit pada ikan kerapu dan kakap di pembenihan dan keramba jaring apung di Bali Utara. Jurnal Riset Akuakultur, 15(2), 89-102. 
Nasukha, A., Septory, R., Sudewi, Setiadi, A., \& Mahardika, K. (2019). Kajian sebaran temporal ammonia dan kualitas fisika perairan di kawasan buangan limbah budidaya laut di Bali Utara. Jurnal Riset Akuakultur, 14(1), 17-27.

Nurhidayu, A., Ina-Salwany, M.Y., Daud, H.M., \& Harmin, S.A. (2012). Isolation, screening and characterization of potential probiotics from farmed tiger grouper (Epinephelus fuscoguttatus). African Journal of Microbiology Research, 6(9), 1924-1933.

Parmar, T., Rawtani, D., \& Agrawal, Y.K. (2016). Bioindicators: the natural indicator of environmental pollution. Frontiers in Life Science, 9(2), 110-118.

Rungrassamee, W., Klanchui, A., Maibunkaew, S., Chaiyapechara, S., Jiravanichpaisal, P., \& Karoonuthaisiri, N. (2014). Characterization of intestinal bacteria in wild and domesticated adult black tiger shrimp (Penaeus monodon). PLOS ONE, 9(3), 1-11.

Sudewi, Widiastuti, Z., Mastuti, I., \& Mahardika, K. (2019). Identification and pathogenicity test of some bacteria isolated from wild and farmed spiny lobster Panulirus Homarus. Berita Biologi, 18(3), 265-272.

Sutarmat, T., Permana, I G.N., Mahardika, K., Giri, I N.A., Pujiastuti, R., \& Andriyanto, W. (2014). Pendugaan limbah nutrien nitrogen dan fosfor dari aktivitas budidaya ikan dalam keramba jaring apung di Teluk Pegametan. Laporan Teknis Kegiatan Kementerian Kelautan dan Perikanan. Balai Besar Penelitian dan Pengembangan Budidaya Laut Gondol (BBRPBL-Gondol), $25 \mathrm{hlm}$.

Sumampouw, 0.J. \& Risjani, Y. (2014). Bacteria as indicators of environmental pollution: Review. International Journal of Ecosystem, 4(6), 251-258.

Todd, P.A., Ong, X., \& Chou, L.M. (2010). Impacts of pollution on marine life in Southeast Asia. Biodivers Conserv, 19, 1063-1082.

Wang, P., J00, J.-H., Park, B.S, Kim, J.-H., Kim, J.H., \& Han, M.-S. (2017). Relationship between dissolved organic carbon and bacterial community in the coastal waters of Incheon, Korea. Oceanological and Hydrobiological Studies, 46(1), 50-61. 